\title{
The false friends problem for foreign norm transplantation in developing countries
}

\begin{abstract}
This article investigates the difficulties in transplanting global legal norms into developing countries, specifically the problem of 'false friends.' This is a linguistics concept describing the situation where there is a striking resemblance between two words in two different languages, leading speakers of each language to assume, incorrectly, that they understand the word's meaning in the other language. Even more problematically, the misunderstanding is hidden by the assumption of understanding. We argue that similar problems can occur when there is a superficial similarity (but a fundamental mismatch) between particular global and local norms. We illustrate this through the example of global intellectual property regimes and their reception in Vanuatu and Mexico, showing how reforms are sometimes welcomed into developing countries on the basis of false assumptions that their aims are congruent with existing understandings. Finally, the paper develops some policy implications for avoiding the 'false friends' problem in a transnational legal context.
\end{abstract}

\section{Introduction}

This paper concerns the complex issue of the transplantation of Western statutory frameworks into developing countries, as is often required by international or bilateral treaty obligations. While these treaty obligations can involve a wide range of subject matter, here we explore the issue through the example of the introduction and strengthening of intellectual property (IP) legislation in developing countries. As with many other subject areas, this routinely involves the transfer of model laws or legislative provisions from developed to developing countries to achieve domestic consistency with global standards. Even for countries already firmly embedded within the 'Western' intellectual-property regime, IP or economic agreements can involve the importation of norms that fundamentally alter the existing policy regime. There is an emerging body of scholarship that is interested in enquiring more deeply into how global norms are actually received in practice at a local level, and what is entailed in terms of changed normative understandings and practices in receiving countries. To date, this scholarship has focussed mainly on human rights, and has often been articulated in terms of questions about how to vernacularise and indigenize foreign concepts in ways that make them meaningful to local audiences. ${ }^{1}$ Similar issues around translation have also recently been raised in the fields of global legal pluralism and the study of transnational legal orders. In this context it is increasingly being recognised that global and local regulatory mechanisms and normative orders are often the result of the interaction and contestation between a range of different

${ }^{1}$ Sally E. Merry, Human Rights and Gender Violence: Translating International Law into Local Justice 2006; Sally E. Merry, 'Transnational Human Rights and Local Activism: Mapping the Middle', in: 108 American Anthropologist (2006), at p. 38; Daniel Goldstein, 'Whose Vernacular? Translating Human Rights in Local Contexts' in Mark Goodale (ed), Human Rights at the Crossroads, at p. 111. 
national, transnational and local bodies, each with a different history of normative ordering. ${ }^{2}$ Both these bodies of literature suggest that processes of transplantation should be conceived of as multi-directional and dynamic, as legal concepts are translated and localised and rearticulated in an ongoing process. This particular take on norm diffusion is in contrast to earlier (and to an extent still existing) understandings about the unidirectional, top-down imposition of foreign norms in which issues of communication were not seen as a problem. A full elaboration of these approaches, however, requires attention to the issues of inter-cultural communication and translation involved in processes of transnational lawmaking.

This paper offers some insights for improved inter-cultural communication of legal concepts by drawing on the linguistic concept of false friends. These are pairs of words that have a similar form and/or pronunciation but different meanings in two languages. ${ }^{3}$ For example, 'sensible' in English means being prudent or wise, but 'sensible' in French means being sensitive. This superficial similarity can lead to the communication of unintentional meanings, unless second-language speakers are made aware of the differences in meanings between the two words or phrases. The field of linguistics, particularly sociolinguistics, has been used by a number of legal scholars to highlight the way in which language and discursive practices can serve to perpetuate the domination by majority groups over politically marginalised groups, such as women and racial and ethnic minorities. ${ }^{4} \mathrm{By}$ engaging with the concept of false friends, we also show how sociolinguistics can also offer insights for assisting inter-cultural legal pluralism, particularly given the emerging emphasis in this field on translation, interpretation, communication and dialogue.

The inspiration for this paper came when the authors realised they shared the same surprising observation from their field sites in Vanuatu and Mexico: in both there is popular support for global intellectual property regimes, even where a pure cost/benefit analysis would suggest that citizens of these countries should be opposed to such laws, as they are likely to hinder access to educational materials, seeds, pharmaceuticals and so forth. ${ }^{5}$ For example, in Mexico, Congress extended the term of copyright to life of the author plus 100 years in 2003 with virtually no public dissent, despite the cost it would impose on its

\footnotetext{
2 Paul Berman, Global Legal Pluralism: A Jurisprudence of Law beyond Borders 2014; Terence Halliday and Gregory Shaffer (eds.), Transnational Legal Orders, 2014.

3 Yusuf Yaylaci and Arman Argynbayev, 'English-Russian False Friends in ELT Classes with Intercultural Communicative Perspectives', in: 122 Procedia - Social and Behavioural Sciences, p. 58. ${ }^{4}$ Diana Eades, 'Legal Recognition of Cultural Differences in Communication: The Case of Robyn Kina', in: 16 Language and Communication (1996), p. 215; Diana Eades, 'I Don't Think It's An Answer to the Question: Silencing Aboriginal Witnesses in Court', in: 29 Language in Society (2000), p. 161. Justin Richland, Arguing with Tradition: The Language of Law in Hopi Tribunal Court 2008.

${ }^{5}$ There is considerable literature on the topic of intellectual property and development. See for a good overview: Tzen Wong and Graham Dutfield, Intellectual Property and Human Development: Current Trends and Future Scenarios 2011; Commission on Intellectual Property Rights (2002), Integrating Intellectual property rights and development policy 2002, http://www.iprcommission.org/graphic/documents/final_report.htm (May 21, 2014).
} 
citizens and the negligible benefit it provides to creators. In Vanuatu, a Least Developed Country, the introduction of a complete raft of intellectual property laws in 2012 was popularly treated as being 'about time' despite its likely negative developmental impacts. ${ }^{6}$

There are many complex reasons why countries sign up to 'bad' intellectual property laws and why there is sometimes little public debate over them. These include the fact that they are often a quid pro quo for access to new markets or favourable trading conditions, the secrecy of many economic-treaty negotiations, and the presence or absence of domestic and international NGOs working on related issues. ${ }^{7}$ Beyond these, the linguistic concept of false friends offers one further insight into what might be happening in the process of translating (or mistranslating) global intellectual property rights concepts locally. For instance, using this insight suggests to us that there is a propensity of citizens and leaders in Vanuatu and Mexico to view global intellectual property regimes through the lens of their existing understandings about rights over intangible culture and knowledge, and therefore make assumptions about such regimes that are often not correct. 8

The paper is structured as follows. First, we situate the concept of 'intellectual property' as an historically contingent, socially constructed means of regulating the production and use of knowledge, information and culture. We then elaborate on the concept of false friends and apply it to the cases of Vanuatu and Mexico, showing how understandings about entrenched local institutions that regulate the production and use of knowledge have affected their interpretation of current IP-reform debates. We conclude with some thoughts on the consequences of the false friends concept for transnational legal orders more generally.

\section{The social construction of intellectual property}

In a paradoxical way, intellectual property offers an important site in which to examine issues of translation and retranslation of ideas and concepts in a transnational setting. It is

${ }^{6}$ See Miranda Forsyth, 'The Developmental Ramifications of Vanuatu's Intellectual Property Commitments on Joining the World Trade Organisation', in: 36 Journal of Pacific Studies (2013) p. 157.

${ }^{7}$ Susan K. Sell, "The rise and rule of a trade-based strategy: Historical institutionalism and the international regulation of intellectual property', in: 17 Review of International Political Economy (2010), p. 762.

${ }^{8}$ There are many other reasons for countries introducing intellectual property laws that are inconsistent with their level of development, with the largest being pressure from international trading partners. However, this pressure cannot account for the phenomenon we are interested in, namely where these laws are introduced without any real opposition and even with popular support. This awkward empirical reality is often glossed over in the literature on intellectual property and development, which tends to portray a polarised debate in which developed countries argue in favour of increased intellectual property rights, and developing countries argue against them. See for example Hugh Laddie, 'Foreword', in CPIR, Integrating Intellectual property rights and development policy, 2002, p. v, http://www.cipr.org.uk/graphic/documents/final report.htm (May 21, 2014). 
paradoxical because, on the one hand, understandings of what is meant by intellectual property (or perhaps, more generally, the regulation of knowledge) today are thoroughly dominated by the economics based, Anglo-American approach that is being spread across the globe through the mechanism of free trade agreements as discussed below. On the other hand, as we show, this is also an area where there are many other competing regulatory approaches at national and sub-national levels, although they are often hidden by the hegemony of the dominant approach.

Intellectual property is often presented as a western concept that was 'invented' with the introduction of the English Statute of Anne of 1710 for copyright and emerging from mid$15^{\text {th }}$ century Vienna in the case of patents, and which has been in development ever since, with a real explosion of different types and degrees of protection since the late $20^{\text {th }}$ century. However, it is clear from anthropological literature that just about every society throughout history has had its own form of intellectual property, in terms of the norms that constrain and permit access to knowledge in its manifest forms. ${ }^{9}$ Indeed, even in societies where real property occupies less importance than in the West, rules of access to knowledge are often highly developed and underpin the structure of the society and its economy. For example, many Pacific Island societies have been operating on the basis of a knowledge economy for thousands of years, as knowledge has traditionally been highly prized and closely regulated, often far more than tangible resources. In many of these societies, power and prestige are closely imbricated with certain bodies of knowledge, such as ritual or medicinal or magical knowledge. ${ }^{10}$ An established Melanesian anthropologist, Lamont Lindstrom, ${ }^{11}$ has even posited a category of 'knowledge-based' polity in the region, '[w]here men achieve power by knowledge alone, control of its production, exchange and consumption is (rather than merely serves) political praxis.' Of course, these different conceptions of intellectual property regulation are dynamic and contested, but it can be confidently stated that that the way in which indigenous intellectual property regimes operate, the interest groups they benefit, and their epistemic and ontological framing, differ considerably from the currently dominant Anglo-American, economics-focused property regimes.

\footnotetext{
${ }^{9}$ Rosemary Coombe, 'Protecting Traditional Environmental Knowledge and New Social movements in the Americas: Intellectual Property, Human Rights, or Claims to an Alternative Form of Sustainable Development?', in: 17 Florida Journal of International Law (2005), p. 115; Marilyn Strathern, 'The Patent and the Malanggan', in: 18 Theory, Culture and Society (2001), p. 1; Eric Hirsch and Marilyn Strathern, Transactions and Creations: Property Debates and the Stimulus of Melanesia, 2004, Berghahn Books; Haidy Geismar, 'Copyright in Context: Carvings, Carvers and Commodities in Vanuatu', in: 32 American Ethnologist (2005), p. 437; Ruth Gana, 'Has Creativity Died in the Third World? Some Implications of the Internationalization of Intellectual Property,' in: 24 Denver Journal of International Law and Policy (1995), p. 109.

${ }^{10}$ Simon Harrison, Fracturing Resemblances: Identity and Mimetic Conflict in Melanesia and the West 2006.

${ }^{11}$ Lamont Lindstrom, 'Doctor, Lawyer, Wise Man, Priest: Big-Men and Knowledge in Melanesia', in: 19 Man, New Series (1984), p. 291, at p. 305.
} 
There are also important cleavages within the dominant Western tradition of intellectual property. Although already subject to the key global IP treaties, such as the Berne Convention (copyright) and the Agreement on Trade-Related Aspects of Intellectual Property Rights (TRIPS), countries embedded in the Western tradition have their own particular balance amongst these different norms and tendencies. Regarding copyright, for example, the dominant Anglo-American approach somewhat obscures the Continental European approach, the former relatively more concerned with economic remuneration and the latter emphasizing copyright (or the author's right) as an author's inalienable moral right and focusing on issues such as the maintaining the integrity of creative works. ${ }^{12}$ While all Western copyright regimes contain elements of both of these approaches, they employ different logics of legitimatization depending on whether they emerged from the AngloAmerican or Continental traditions - the former stressing economic efficiency for the former, the latter human rights - and can lead to significantly different policy focuses. For example, when copyrights are traded as an asset, intermediaries such as publishers become much more prominent than actual creators, since they are the actors that control the majority of economically valuable copyrights (which authors sign over in order to get their works published). Given this prominence, the voice and interests of intermediaries can supersede those of authors in the policymaking process. The United States, which has been the strongest proponent for ever-stronger economic rights in copyright, including establishing criminal sanctions for unauthorized copying, is the epitome of a country in the Anglo-American tradition. In contrast, as we discuss below, Mexico traditionally hewed closer to the Continental European/moral rights side of the equation.

Increasingly, indigenous and local conceptions of intellectual property are coming into contact with the dominant Anglo-American, economics-focused approach. In developing countries this most usually occurs through the negotiation of economic agreements, including free trade agreements (FTAs). Intellectual property rights have become a key part of the global trade regime, most prominently with the formation of the WTO in 1995. As part of the condition for joining the WTO, members are required to sign up to the TRIPS, which mandates minimum standards of intellectual property protection across a range of areas including copyright, trademark, patent, industrial design, geographical indications, undisclosed information and layout designs of integrated circuits. Other FTAs often require countries to sign up to 'TRIPS Plus' standards of protection, that go above these minimum international standards. In this paper we refer to all of these as 'global intellectual property rights.'

Beyond these treaties, domestic intellectual property laws themselves are extremely technical and inaccessible to the layperson. Trade negotiators, politicians, lobby groups and the general public are consequently obliged to rely on general narratives about intellectual property laws when discussing intellectual-property reform. At this level of generality, such

${ }^{12}$ Reynaldo Urtiaga Escobar, 'Los sistemas de derechos de autor y copyright hoy', in: Año II Revista Mexicana Del Derecho de Autor Año (2002), p. 11. 
narratives often rely on pre-existing local understandings about intangible property rights, which are used to legitimize any reforms. By the time the disjuncture between the old and the new systems becomes apparent, it is often too late to do anything about it - the FTA has been signed, the model legislation has been passed, and the changes have taken root.

\section{False friends, translation and diffusion}

With the constructivist turn in the social sciences, the importance of ideas as a direct influence on policymaking is by now widely accepted. ${ }^{13}$ Social constructivism holds that our perception of reality is shaped by our shared ideas about actually existing, material, reality. In a socially constructed world, moreover, ideas and meanings are not static; through communication, they can be challenged and changed. Of particular interest in the context of this paper (and setting the scene for our discussion of the 'false friends' phenomenon) are two related modes of idea transmission: diffusion and translation. Diffusion is 'the process by which an innovation is communicated through certain channels over time among the members of a social system'.14 Implied in the concept of diffusion is the existence of an 'inside' and an 'outside,' that an innovation - an idea - must go from where it is to a place where it is not. In this article, for example, we examine the diffusion of global (and, more specifically, market-based) conceptions of intellectual property from the global North (especially the United States) to the global South, including to countries already embedded in the main IP treaties, but with domestic IP regimes that differ from those of the main IP powers. While our specific cases refer to international policy diffusion across national borders, policies, concept and ideas can be also be diffused across non-territorial borders. Although 'place' often refers to geographic entities, particularly countries, it can just as easily refer to cultures, issues, or disciplines, as when a musician like Kanye West claims to be influenced by ideas and concepts in architecture or high fashion. ${ }^{15}$ Furthermore, policy/ideational diffusion can be more or less voluntary or coercive; more accurately, the idea/policy transfer lies 'along a continuum that runs from lesson-drawing to the direct imposition of a program, policy or institutional arrangement on one political system by another'.16

${ }^{13}$ E.g., James G. March and Johan P. Olsen, 'The New Institutionalism: Organizational Factors in Political Life', in: 78 The American Political Science Review (1984), p. 734; Peter A. Hall and Rosemary C.R. Taylor, 'Political Science and the Three New Institutionalisms', in: 44 Political Studies (1996), p. 936; Alexander Wendt, Social Theory of International Politics 1999; Daniel Béland and Robert H. Cox (eds.), Ideas and Politics in Social Science Research 2011; Vivian A. Schmidt, 'Taking Ideas and Discourse Seriously: Explaining Change through Discursive Institutionalism as the Fourth 'New Institutionalism", in: 2 European Political Science Review (2010), p. 1.

${ }^{14}$ Johnson and Hagström 2005: 366.

15 Jesse Serwer, 'Kanye West: 'My Next Album Is Going to Be Eight Songs', in: Rolling Stone, December 5, 2013, http://www.rollingstone.com/music/news/kanye-west-my-next-album-is-going-to-beeight-songs-20131205

${ }_{16}$ David P. Dolowitz and David Marsh, 'Learning from Abroad: The Role of Policy Transfer in Contemporary Policy-Making', in: 13 Governance: An International Journal of Policy and Administration (2000), p. 5-24 
Translation, meanwhile, refers to the process of adoption and adaptation of new ideas diffused across borders, be they geographic, cultural, or disciplinary. In the social world, there is no terra nullius. All of our lives are embedded in previously existing institutions (defined by Hall and Taylor as 'the formal or informal procedures, routines, norms and conventions embedded in the organizational structure of the polity or political economy'17). Furthermore, all societies are governed by formal or informal rules addressing basic functional requirements of all societies - the distribution and redistribution of material wealth, intra- and inter-societal relations, the regulation of knowledge, and so on. This is the point made by legal pluralists who stress the rarity of a social field with a single form of ordering, and thus the unreality of claims by legal positivists that state law is the only relevant site of enquiry. ${ }^{18}$ It would be highly unusual for a society to have no rules to consult in dealing with a situation. Even in novel situations, individuals and groups tend to look for analogies in their previous experiences. As a result, when ideas and legal concepts are diffused across borders, they must be incorporated - translated - into local 'practice in unique ways that fit with prevailing national political institutions'. ${ }^{19}$ Merry calls this process of reframing ideas within a new cultural framework the process of vernacularisation. ${ }^{20}$ She also draws attention to the role that intermediaries, such as community leaders, activists and members of NGOs, play as 'knowledge brokers' between culturally distinct social worlds. ${ }^{21}$

Translation of legal concepts is becoming an increasingly important part of transnational norm development and global regulation in general. This follows from growing acceptance that foreign legal concepts and instruments are rarely simply transplanted from one system to another in a neutral manner, but rather are hybridized and reworked. Intermediaries who perform legal and conceptual translation work, like language translators, need techniques and strategies to assist them, and one such technique that we propose here is associated with the concept of false friends.

\section{False friends}

As noted above, linguists use the expression 'false friends' to describe the situation where pairs of words or phrases in two languages look or sound similar, but differ significantly in

\footnotetext{
${ }^{17}$ Hall and Taylor, 'Political Science and the Three New Institutionalisms', at p. 938.

${ }^{18}$ John Griffiths, 'What is Legal Pluralism', in: 24 Journal of Legal Pluralism (1986), p. 1; Miranda Forsyth, A Bird that Flies with Two Wings: Kastom and State Justice Systems in Vanuatu 2009, http://epress.anu.edu.au/kastom citation.html (May 21, 2014).

${ }^{19}$ John L. Campbell, 'Ideas, Politics, and Public Policy', in: 28 Annual Review of Sociology (2002), p. 21, at p. 31.

${ }^{20}$ Merry, Human Rights and Gender Violence, at p. 1.

${ }^{21}$ Merry, 'Transnational Human Rights and Local Activism'; see also Holly Wardlow, 'The Task of the HIV Translator: Transforming Global AIDS Knowledge in an Awareness Workshop', in: 31 Medical Anthropology (2012), p. 404.
} 
meaning. ${ }^{22}$ Language learners hear the word in the other language and assume, falsely, that they know what it means as it sounds so similar to their own language. The consequences of falling into the 'false friends' trap range from embarrassment to mutual incomprehension. False friends can be particularly treacherous as they are often hidden and the context may offer no hint of the fact that the meaning is quite different in the two languages. ${ }^{23}$ Awareness of the false friends problem is therefore important in a range of linguistic contexts, such as language learning and translation. For example, Yaylaci and Argynbayev argue that drawing conscious attention to specific false friends and developing techniques and strategies to raise awareness of them 'can contribute to the development of intercultural competence'.24

The false friends concept can be used as a way of revealing the existence of competing similar-but-different legal concepts that might otherwise remain hidden. It can be used to draw attention to the fact that in some situations, policymakers and the general public respond to a 'foreign' concept as equivalent to a domestic one without realising the fundamental differences between them. For example, the introduction of Western legal norms, such as global intellectual property rights, into non-Western settings can lead to situations where non-Western policymakers respond to the narrative of intellectual property on the basis of their existing understandings about the protection of knowledge. They assume that they know what this narrative is all about, because it resonates with similar sounding concepts in their own society, and as a consequence may be less questioning of its potential disadvantages than they should, and may legitimize harmful policies, making them harder to dislodge over time. Drawing attention to this false friend problem can allow intermediaries involved in the translation exercise to short-cut any misunderstandings that might arise otherwise.

To date, the discourse around the problem of false friends has largely been confined to the discipline of linguistics. However, socio-linguists such as Diana Eades have been extending linguistic analysis generally into the legal arena. For instance, her work reveals the problems in communication caused by misunderstandings of Aboriginal English in Australian Law Courts. She observes that people often assume they are communicating when in fact they are not, and that this is particularly problematic when the differences in language are not apparent. ${ }^{25}$ Her work has shown how these misunderstandings can have severe consequences, sometimes ending in miscarriages of justice. ${ }^{26}$ As a result, she holds

\footnotetext{
${ }^{22}$ Robert Hill, A Dictionary of False Friends 1982.

${ }^{23}$ See Pedro Dominguez and Brigitte Nerlich, 'False Friends: Their Origins and Semantics in Selected Languages', in: 34 Journal of Pragmatics (2002), p. 1833.

${ }^{24}$ Yaylaci and Argynbayev, English-Russian False Friends in ELT Classes with Intercultural Communicative Perspectives', at p. 64.

25 Diana Eades, 'Assuming Communication: Institutional Interactions with Aboriginal People', conference presentation, Australian National University, Canberra, Australia, September 8, 2013. ${ }^{26}$ Diana Eades, Aboriginal Ways of Using English 2013; Eades, 'I Don't Think It's an Answer to the Question'; Eades, 'Legal Recognition of Cultural Differences in Communication'.
} 
regular training courses for judges and magistrates in which she urges them to be open to the possibility that some expressions used by indigenous Australians may not have the same meaning to non-indigenous Australians, even though they are all speaking 'English'. She has succeeded in having the Aboriginal Benchbook for Western Australia require judges to draw the jury's attention to the possibility that sociolinguistic features of an Aboriginal witness' evidence may lead to misunderstandings. ${ }^{27}$

The problem of false friends has also been incorporated into the development of teaching strategies to improve intercultural communication. Yaylaci and Argynbayev explain that this is a complex phenomenon, which can be briefly defined as the abilities needed to perform effectively and appropriately when interacting with others who are linguistically and culturally different. ${ }^{28}$ They use Bennett's model of intercultural communication which starts with the denial of the target culture. This denial stage is often the one in which legal transplantation occurs as a result of the hegemonic dominance of many dominant global legal concepts. The work of scholars such as Merry points towards ways that this denial stage can be moved past, by demonstrating the importance of taking cognisance of existing local ways of framing concepts and ideas. The other stages of learning intercultural communication involve acceptance of cultural difference, and finally, the adaptation stage in which 'the learner effectively participates in the communicative process with the target culture by intentionally changing his own behaviour and communication style'. ${ }^{29}$ Yaylaci and Argynbayev argue that false friends tend to slow down the process of intercultural communication at all stages, which is why explicit strategies are needed to draw attention to them.

Not only leaders and policymakers are vulnerable to the problem of false friends. Its effect is general. It influences both elites' acceptance of massive reform, as well as the public's understanding of policy changes implemented by elites. In the latter case, one might argue that this is merely 'smart politics,' with politicians cynically selling a revolutionary policy reform by framing it in terms of an existing framework. We argue that this is an example of deliberately exploiting false friends to deceive the public. The public hears the false friend, and is reassured that nothing is changing, even if the politicians selling the change know better.

In an attempt to improve intercultural communication about legal concepts, we therefore now turn to highlighting the potential false friends problem that exists in intellectual property, and show how failure to recognise it affected intellectual property policy in a Least Developed Country, Vanuatu, and a key developing country, Mexico.

${ }^{27}$ See Stephanie Fryer-Smith, Aboriginal Benchbook for Western Australia Courts 2008.

${ }^{28}$ Yaylaci and Argynbayev, English-Russian False Friends in ELT Classes with Intercultural Communicative Perspectives'.

${ }^{29}$ Yaylaci and Argynbayev, English-Russian False Friends in ELT Classes with Intercultural Communicative Perspectives', at p. 61. 


\section{But the New Zealanders will have to pay for the bungee jump, right? Vanuatu and accession to the World Trade Organization}

Vanuatu is a small archipelago located in the area of the Pacific Islands known as Melanesia, with a population of roughly 250,000 . Previously colonised by both the French and the English, it gained independence in 1980. Vanuatu has the formal structures of a nation state, with a democratic political system and a legal system based very heavily on its colonial past. However, Vanuatu also continues to have vibrant customary governance and legal institutions that perform important functions, especially in the rural areas where the vast majority of the inhabitants (known as ni-Vanuatu) continue to live as subsistence farmers. The relationship between the customary systems and the state is complex and often contested. ${ }^{30}$ As an integral part of this customary system, Vanuatu has well established institutions (by which we mean norms and the structures that administer them) regulating the production and use of knowledge and intangible cultural property. These institutions have their roots in a traditional past, but like all living regulatory systems they continue to change, adapting to new local and global circumstances, and responding to political and economic struggles between different interest groups. ${ }^{31}$ Whilst these institutions are themselves highly diverse, a number of key features typical of many indigenous intellectual property institutions in Vanuatu are discussed through the examples below.

In the Northern islands of Vanuatu, there is a ceremonial ranking system, whereby men, and occasionally women, achieve power and prestige by passing through a series of ranked grades. ${ }^{32}$ As part of membership of such grades, participants obtain particular sets of rights and privileges, and have access to particular clusters of ritual knowledge not commonly known. Although this system has changed (and diminished) considerably over time, it continues to be of real importance in establishing legitimacy and prestige for leaders at both local and national levels today..$^{33}$ On Ambrym, one of the Northern islands, one of the sets of rights obtained through the graded society is the right to carve vertical slit drums known widely as tamtams. These drums have different design faces associated with different ranks, and may involve as many as five faces on top of each other. Importantly, the right to carve

\footnotetext{
${ }^{30}$ See generally Forsyth, 'A Bird that flies with Two Wings'.

31 There is a rich body of ethnographic literature that examines rights over intangible cultural heritage in Vanuatu and Melanesia more broadly. See for example: Malinowski, Bronislaw 1922, Argonauts of the Western Pacific. London: Rutledge and Kegan Paul; Huffman 1996; Lamont Lindstrom, 'Arts of Language and Space, South-East Tanna', in Jean Bonnemaison et al (eds.), Arts of Vanuatu, 1996, p. 123; Strathern, 'The Patent and the Malanggan'; Simon Harrison, Stealing People's Names: History and Politics in a Sepik River Cosmology 1990. Harrison, 'Fracturing Resemblances'; Steffen Dalsgaard, 'Claiming Culture: New Definitions and ownership of Cultural Practices in Manus Province, Papua New Guinea', in: 10 The Asia Pacific Journal of Anthropology (2009), p. 20; Geismar, 'Copyright in Context'; and Geismar, Treasured Possessions.

32 Michael Allen, 'Rethinking Old Problems: Matriliny, Secret Societies and Political Evolution', in: Michael Allen (ed.), Vanuatu: Politics, Economics and Ritual in Island Melanesia, 1981, p. 9, at p. 24. ${ }^{33}$ For example, many politicians and others with high government positions expend considerable resources in gaining new customary titles.
} 
these designs is considered to be separate from the ability or skill to do so, meaning that carvers may buy the rights to reproduce the design from those who have rights over it as a result of their membership of the particular grade. ${ }^{34}$ These rights are traded through the use of ritual currencies of pigs and yams and, increasingly, cash, as tamtams have become valuable commodities in the international art market. Geismar states:

A carver must pay, through various types of ritual practice and, increasingly, with money for the rights to both produce (carve) and circulate (sell) kastom images. Owners of designs may commission carvers to reproduce them, retaining ownership nonetheless ... Complex relations of patronage, hierarchy, and customary authority therefore are embodied in the social form of the ritual complex'. ${ }^{35}$

Another example of a local intellectual property institution in Vanuatu are the sets of rights around the transfer of music. One dimension of this practice is described by ethnomusicologist Monika Stern as follows:

In Vanuatu some people are recognised as song specialists, a kind of composer... .. Maurice, an elderly composer ... explained to me that, if someone commissions a song from him, he composes it and gives it to the person in exchange for a payment. The composer himself must forget the song, because, henceforth, it belongs to the person who commissioned it. The explanation of the 'forgetting' composer is very explicit concerning the existence of rights to music.... There is a close connection between spirit entities and composition. Most of the time, people believe that a song or a dance was brought to the living ancestors' spirits in dreams while asleep or walking alone in the bush.... This super-natural origin of songs is an important part in the conception of rights because it plays a large part in the protections of songs ... . Magic ensures that [the rule over payment and transfer of rights] is respected. ${ }^{36}$

Dances are also created and rights over them exchanged in a similar way, the memory of which can be transmitted along with a community's corpus of songs and dances. For example, in a recent book describing the dances in Erromango (another island in Vanuatu), it is noted that today there are seven women's dances and three men's dances that people remember. It then notes, 'In reality, there should be four men's custom dances but our Erromangan ancestors traded one of these dances, the niyeli, with people on Tanna [another island]'. ${ }^{37}$

\footnotetext{
${ }^{34}$ Haidy Geismar, 'Copyright in Context: Carvings, Carvers and Commodities in Vanuatu', in 32 American Ethnologist p. 437 at p. 443.

35 Geismar, 'Copyright in Context', at p. 442.

${ }^{36}$ Monica Stern, 'Music in Traditional Exchanges in North Vanuatu' , in: 36 Pacific Studies (2013), p. 59, at pp. 64-65.

${ }^{37}$ Anna Naupa, Kastom and Culture of Erromango 2011, at p. 38.
} 
These brief examples allow us to make a number of observations about Vanuatu's indigenous intellectual property systems. They demonstrate that knowledge and other intangibles, such as designs, songs and dances, were and continue to be highly valued and able to be traded, with complex rights over their use and transfer. Second, these rights were enforced through customary norms and mechanisms, such as demands for compensation, war and, importantly, magic or sorcery. Third, indigenous intellectual property is often deeply linked to both claims for, and the exercise of, political power. This is particularly observed in the first example where we saw that power as obtained through the graded system is embodied in particular designs, such as those of the anthropomorphical tamtams. Further, the exploitation of these rights and the control they give over important ritual and creative practices often enable revenue streams to be consolidated into the hands of the most senior and powerful individuals. Geismar observes that 'the graded societies are a prime mechanism for the distribution of entitlement, creating a political economy that allocates control over local resources - which range from the prime ritual currency of pigs to yams, knowledge and, increasingly, cash - to the highest-ranking men'.38 Stern also concludes that 'knowledge is cultural and economic wealth', 39 and similar observations have been made by Lindstrom, who argues that in some societies in Melanesia, power depends upon the control of knowledge rather than wealth. ${ }^{40}$ Finally, rights over intangible valuables form a part of the complex exchange system around which social, political and economic life in Melanesia was, and to a considerable extent, is still, based.

Unsurprisingly, analogies between these customary understandings of reproductive control over designs, and Western notions of intellectual property have been drawn repeatedly by anthropologists working in region. Thus Huffman refers to the Vanuatu 'copyright' system, which 'recognizes certain individuals, groups or areas as the proper owners of cultural items, the rights to which can be purchased, sold and resold over large areas in the perpetual spiritual and material drive upwards and outwards towards increased social height, prestige, power and influence in the world of the living and the world of the ancestral spirits'. ${ }^{41}$ Lindstrom similarly refers to '[t]raditional copyright or patents [that] protect valued knowledge, including songs, myths, histories, genealogies and herbal cures, as well as artistic motifs carving designs' ${ }^{42}$ In the similar context of PNG, anthropologists have even debated whether the analogy of copyright or patent is the most applicable to certain complexes of rights, such as the Malanggan of New Ireland. ${ }^{43}$

Similar analogies between Western and indigenous knowledge categories are also increasingly being drawn by the ni-Vanuatu themselves and other inhabitants of the Pacific

${ }^{38}$ Geismar, 'Copyright in Context,' at pp. 441-442.

${ }^{39}$ Stern, 'Music in Traditional Exchanges in North Vanuatu', at p. 71.

${ }^{40}$ Lindstrom, 'Doctor, Lawyer, Wise Man, Priest'.

${ }^{41}$ Kirk Huffman, "Trading, cultural exchange and copyright: important aspects of Vanuatu arts", in Joel Bonnemaison et al (eds.), Arts of Vanuatu, p. 182, at pp. 182-183.

${ }^{42}$ Lindstrom, 'Arts of Language and Space, South-East Tanna', at p. 127.

${ }^{43}$ Strathern, 'The Patent and the Malanggan'. 
Islands region. Geismar observes 'the historical emphasis of copyright law on external manifestation has given the phrase 'copyright' great resonance with communities who are interested in protection of the circulation of their cultural knowledge and recognize that the complex relationship between knowledge and its materialization is crucial to their own selfdetermination'. ${ }^{4}$ She argues that the term 'copyright' has passed into local parlance, and has moved beyond being 'like' or analogous to indigenous understandings, to have become actually incorporated into the way in which rights from the graded society are discussed and implemented. ${ }^{45}$ Geismar's research finding that 'nearly everyone' made explicit linkages between copyright and the indigenous intellectual property system ${ }^{46}$ is consistent with one of the co-authors' own fieldwork, spanning over ten years in Vanuatu. She also found people consistently assuming that they know what copyright 'is' based on their understandings of their indigenous intellectual property system.

Geismar sees these explicit parallels as being empowering for local communities, and celebrates the political use that can be made of the appropriation of the international language of intellectual property. For example, she demonstrates that Ambrymese men have been able to use the language of copyright to assert their rights over tamtam designs in a national context to prevent foreigners from trading in such carvings. ${ }^{47}$ She asserts that 'IPR [intellectual property rights] legislation itself is as able to incorporate difference and to assimilate diverse understandings of entitlement as it is to be exploited to demonstrate geographic and conceptual differences'. ${ }^{48}$ However, we argue here that there are also dangerous and negative consequences of this identification between the two concepts, which can be seen through the false friends concept we have described above. In particular, this identification risks causing a certain blindness to the fundamental differences between the two systems, differences that are heavily weighted through geo-political realities to shift the balance of power (and transfer of rents) from the local to the outside world.

The problem of the false friend in the case of Vanuatu can be demonstrated by its recent accession to the WTO. Vanuatu inherited a very patchy intellectual property system from England upon achieving independence in 1980. A few colonial laws providing for the reregistration of patents and trademarks were re-enacted, and arguably the Copyright Act 1956 (UK) theoretically applied. ${ }^{49}$ However, the system effectively languished, virtually

${ }^{44}$ Geismar, Treasured Possessions, at p. 87.

${ }^{45}$ Geismar, Treasured Possessions, at p. 88.

${ }^{46}$ Geismar, 'Copyright in Context', at p. 441.

47 Geismar, 'Copyright in Context'.

${ }^{48}$ Geismar, 'Copyright in Context', at p. 440.

${ }^{49}$ Section 95(2) of the Constitution provides that English laws of general application continued to apply after Independence (in 1980) to the extent that they are not expressly revoked or incompatible with the independent status of Vanuatu. The High Court of the New Hebrides Regulation 1976 provided that the British statutes in force were '... so far as circumstances admit ... the statutes of general application in force in England on the first day of January 1976' (Jennifer Corrin-Care, Tess Newton Cain and Don Paterson, Introduction to South Pacific Law 1999, at p. 55). 
unused until interest was reignited by Vanuatu's first bid to accede to the WTO, which began in July 1995 and was withdrawn in $2001 .{ }^{50}$ As part of this bid, a raft of intellectual property laws were drafted, modelled in part on Australian and New Zealand legislation and generic UNESCO and WIPO guidelines, but also containing some locally drafted provisions on indigenous knowledge and expressions. ${ }^{51}$ This legislation then remained in limbo for over ten years but was finally gazetted in 2011 as part of Vanuatu's second, and ultimately successful, bid to accede to the WTO.

Vanuatu's intellectual property commitments required to accede to the WTO were exceptionally onerous, ${ }^{52}$ and indeed are the most burdensome of all the Least Developed Countries and Small Islands Developing States that joined the WTO in the last ten years. ${ }^{53}$ Vanuatu was not permitted to take full advantage of any of the flexibilities that were available to it as a Least Developed Country, and it was required to commit to several TRIPS Plus provisions. ${ }^{54}$ There is no doubt that the explanation for the extent of Vanuatu's 'bad' intellectual property commitments is complex. It includes the fact that the technical rules of intellectual property were likely to have been beyond the capacity of the trade negotiators, the pressures that were on Vanuatu to accede from foreign trading partners, and the lack of informed and active national lobby groups with understandings of intellectual property. A major factor is also likely to be the structural constraints that restrict the bargaining power of acceding members. Grynberg and Joy argue: 'Accession is biased against the applicant and the process gives enormous powers to the WTO members to extract concessions that would not be possible in a genuinely rule-based system' ${ }^{55}$ Despite these structural

\footnotetext{
${ }^{50}$ Daniel Gay, 'Vanuatu's Suspended Accession Bid: Second Thoughts?, World Trade Organisation Case Study 43, no date, http://www.wto.org/english/res e/booksp e/casestudies e/case43 e.htm (May 21, 2014).

51 Michael Wright, 'Traditional Knowledge Protection: International, Regional and National Experiences; Legislative Initiatives in Vanuatu to Protect Expressions of Indigenous Culture', paper presented at workshop for Legal Experts on the Protection of Traditional Knowledge and Expressions of Culture, Noumea, New Caledonia, 15-19 February 1999, cited in Geismar, Treasured Possessions, at p. 78.

52 The accession package is set out in the WTO Working Party report, Document WT/ACC/VUT/17, http://www.wto.org/english/thewto e/acc e/completeacc e.htm\#vut, (May 21, 2014)

53 The others were Tonga, Nepal and Cambodia. For example, Vanuatu used the least number of years as a transition period, agreed to join UPOV when Nepal and Tonga managed to avoid this, agreed to linkage during the transition period when Nepal avoided this, indicated 'readiness to join' the Patent Cooperation Treaty which Nepal and Cambodia avoided, and the administrative resource commitments are more onerous than any of the other countries in that they specify the number of officials to be trained, require the establishment of an institution and recruitment of staff, and also the obtaining of facilities and equipment.

${ }^{54}$ Such as committing to signing the WIPO Copyright Treaties, becoming a party to UPOV, providing for data exclusivity and linkage.

${ }^{55}$ Roman Grynberg and Roy Mickey Joy, 'The Accession of Vanuatu to the WTO. Lessons for the Multilateral Trading System', in: 36 Journal of World Trade (2000), p. 159, at p. 160; see also Joanne
} 
constraints, other Least Developed Countries acceding around the same time managed to avoid certain of the extra commitments that Vanuatu agreed to. For example, Nepal avoided committing to high levels of protection over plant varieties, partly on the basis of a strong public campaign. ${ }^{56}$ Consequently, we need to look for other explanations as well. We argue that the false friends problem was a meaningful factor in causing ni-Vanuatu negotiators and politicians to more readily accept onerous intellectual property commitments. In other words, one reason for Vanuatu's acceptance of high levels of global intellectual property was the incorrect assumption that the global system works in a similar way to some of the underlying principles of Vanutau's indigenous intellectual property systems. This can be demonstrated by looking at some of the comments made by politicians during the accession process.

A constant refrain during the entire decade on which WTO membership was on the table in Vanuatu, was that joining the WTO will allow ni-Vanuatu to get financial recognition for inventing bungee jumping. The creators of the bungee jump were indeed apparently initially inspired by seeing Pentecost Land Diving, in which men jump from high towers with vine ropes tied around their ankles. ${ }^{57}$ However, whereas it is clear that in Vanuatu custom that only the people from the island of Pentecost can perform the Land Dive, 58 there is no western intellectual property right that can be used to make any legal claim over the creators of bungee jumping. Nevertheless, the Minister for Trade argued on the radio in August 2011:

One of the benefits I think we should have from joining the WTO is to ask some of the countries who have copied our practices to have paid us some money. In saying this I refer to the land diving on Pentecost, when it was taken by someone from New Zealand and then they decided to put up this bungee jump. And I think maybe one of the things we join the WTO for ... it would give help to us for this company to give us some money .... .59

Wallis, "Friendly Islands' in an unfriendly system: examining the process of Tonga's accession to the WTO', in: 51 Asia Pacific Viewpoint (2010), p. 262, at p. 270.

56 Tone Winge, Kamalesh Adhikari and Regine Andersen, 'Advocacy for Farmers' Rights in Nepal ' in Regine Andersen and Tone Winge (eds.), Realising Farmers' Rights to Crop Genetic Resources: Success Stories and Best Practices 2013, p. 181.

${ }^{57}$ Miranda Forsyth, 'Lifting the lid on 'the community': Who has the right to control access to traditional knowledge and expressions of culture?', in: 19 International Journal of Cultural Property (2012), p. 1, at p. 19.

${ }^{58}$ Margaret Jolly, 'Kastom as Commodity: The Land Dive as Indigenous Rite and Tourist Spectacle in Vanuatu', in Lamont Lindstrom and Geoffrey White (eds.), Culture, Kastom, Tradition: Developing Cultural Policy in Melanesia, 1994, p. 131.

${ }^{59}$ Pacific Beat, 'Vanuatu Minister warns against delaying WTO membership', 17 August 2011, Radio Australia, http://www.radioaustralia.net.au/international/radio/onairhighlights/vanuatu-trademinister-warns-against-delaying-wto-membership (May 21, 2014). 
Another example of the confusion in conceptual understanding as a result of the false friends problem is the protection of traditional or customary names, such as the names of spiritual places or particular ranks of chief. Names are of great importance throughout Melanesia, and have their own worth. ${ }^{60}$ To this day in Vanuatu, if a person wishes to name a child after someone then they must present the namesake with a gift (as has happened to one of the co-author's husband and daughter). These customary understandings of the importance of respecting rights to names are nowadays often confused with trademark law, despite the purpose and operation of the two systems being very different. Consequently, one reason put forward by a Member of Parliament in the course of parliamentary debates over the introduction of intellectual property law amendments was that intellectual property laws are needed to protect ni-Vanuatu names. He stated: 'If we do not do this, anyone, for example in China can use the name Yasur or Nagol and we cannot do anything about it, but now an individual from Tanna and Pentecost can register these names'.61 (Joshua 2011). His argument reflects the fact that under ni-Vanuatu customary law, a non ni-Vanuatu would not have any rights over a name associated with a particular Vanuatu locality (Yasur is a volcano) or ritual (Nagol is the vernacular name for the Land Dive). However, under international trademark law, due to the national treatment principle, there can be no discrimination upon the basis of nationality of the applicant.

A final example is the reference in public debates to the need to have intellectual property laws to protect the natural resources that are closely intertwined with ni-Vanuatu identity, such as kava, yams and traditional medicine. A MP stated 'Manples [citizens] want to protect themselves and the government is putting this system in place to protect our natural resources'.62 Under customary law there is a complex system for determining rights over genetic resources, which entitle individuals and groups to claim certain rights. ${ }^{63}$ However, under intellectual property laws, particularly patent law, which was the immediate context for this debate, natural phenomena and naturally occurring products are not patentable. ${ }^{64}$ This point also relates to a further common perception in the area of intellectual property policy in developing countries - the tendency to over-value one's own nation's (or

60 For example, Harrison (Stealing People's Names) describes a society in PNG where names are the highest economic currency and the entire political and economic structure of the society revolves around their control and transmission.

61 Jane Joshua, 'Patents Amendment Bill Isolated from Vanuatu's Accession to WTO: Kaltongga', Vanuatu Daily Post, 5 December 2011, http://www.dailypost.vu/content/patents-amendment-billisolated-vanuatu\%E2\%80\%99s-accession-wto-kaltongga (May 21, 2014).

62 Joshua, 'Patents Amendment Bill Isolated from Vanuatu's Accession to WTO: Kaltongga'.

${ }^{63}$ Miranda Forsyth and Sue Farran, 'Intellectual Property and Food Security in Least Developed Countries', in: 34 Third World Quarterly (2013), p. 516.

${ }^{64}$ Although of course this boundary is constantly being challenged in new ways. For the moment the most authoritative pronouncement is by the US Supreme Court that held in the Myriad genetics case that a genetic sequence used as part of a test for breast cancer could not be patentable. The court held that a 'Groundbreaking, innovative, or even brilliant discovery' is still not enough to constitute patentable subject matter. See Association for Molecular Pathology v Myriad Genetics, Inc. 133 US 2107 (2013). 
community's) original contributions to the world, and to minimise the extent to which outsiders' contributions are relied upon. For example, in the debates over the introduction of new patent law amendments, an MP argued, 'it is important and simple - if an indigenous ni Vanuatu invents or produces something no one has ever done it has to be protected'.65 At no point in the discussion was there reference to the cost that this may entail in terms of having to respect the rights of the rest of the world's inventions. Nor was there acknowledgment of the fact that Vanuatu does not currently have a national research and development institution, and so the chances of producing a patentable invention are highly limited.

A further example comes from a 2013 newspaper report describing a visit by officials to Penama Province by Trade Officials. The report states:

One of the top topics discussed was the Intellectual Property (IP) or Vanipo office. The participants and the people of various places visited including Asanvary of south Maewo were very interested about the IP and questioned why the office took so long to establish. They were very impressed and felt that the office should have been established long ago to protect their traditional ways of living, especially the custom dances and the artifacts. The general feeling about the establishment of the IP office was that it will only encourage innovative and creative ideas (Vanuatu Daily Post 2013).

However, there is nothing in the global intellectual property system to protect traditional ways of living. Nor is it, alone, likely to make a meaningful incentive for innovation and creativity, at least in the short to medium term.

This issue of conflicting understandings of 'intellectual property' is further muddied by the introduction of the traditional knowledge discourse into trade negotiations in high-level regional forums, and by WIPO in their awareness raising workshops in developing countries. Whether purposively or not, intellectual property and traditional knowledge are often discussed together in these forums. However, little attention is given to distinguishing the enormous differences in the international treatment of the two areas. Whilst intellectual property regimes are part of an established international framework that facilitates their enforcement globally through TRIPS and complicated web of FTAs, traditional knowledge is not currently protected outside national borders, ${ }^{66}$ and often not even within them. Dealing with the two issues together in FTA negotiations means that these fundamental differences are difficult for those not trained in intellectual property to perceive, and there is an implicit suggestion of equal treatment. For example, the 2013 Pacific Islands Forum Secretariat Forum Trade Ministers Meeting stated in its Outcome Statement:

\footnotetext{
65 Joshua, 'Patents Amendment Bill Isolated from Vanuatu's Accession to WTO: Kaltongga'. ${ }^{66}$ There is a treaty drafting process in place at the WIPO Intergovernmental Committee on Intellectual Property and Genetic Resources, Traditional Knowledge and Folklore.
} 
Ministers highlighted the importance of TK \& IP initiatives in preserving and securing their culture and arts, and noted the efforts of their Cultural Ministries to preserve their culture. The need for the region to become part of an international arrangement for the protection of TK and IP was encouraged and the respective technical agencies were requested to assist the Members accordingly. 67

This statement demonstrates the clear connection perceived by many in the region between traditional knowledge and intellectual property, and the misguided belief that they are both protected at an international level. It also demonstrates the widespread perception that global intellectual property laws are valuable in preserving culture, and no discussion about any potential disadvantageous development consequences (such as administrative costs, limitations in accessing pharmaceuticals, seeds and textbooks). ${ }^{68}$

\section{Mexico: New regime, old justifications}

The effect of the false friends problem is most obvious in a situation like Vanuatu's, where there exists a marked contrast between the pre-existing knowledge-regulation regime and the intellectual property regime that originated in Europe. As a country with a long history of integration into the mainstream of global copyright thought and treaties, Mexico might seem to be an odd example to use to demonstrate the concept of false friends. However, we argue that the term can also be used to understand changes in intellectual-property regimes within the Western world. The concept of 'intellectual property' should not be thought of as a monolithic, internally consistent thing, but rather as a bundle of norms. Some of these norms exist in tension with each other, such as the protection/dissemination paradox: 69 providing protection to knowledge impedes its dissemination by restricting the conditions under which it can be shared. Other IP norms have little logical relation to each other (such as copyright's economic and moral rights strains). Specific, actually existing copyright regimes differ on how they balance these bundles of norms, according priority to some goals (protection and moral rights, say) than others. Changing the relative importance of these goals can thus have a significant real effect on a country's intellectual-property policy, even if it remains recognizable as a Western-style "intellectual property" regime.

At heart, the concept of false friends refers to two dissimilar regimes that share a superficial resemblance but that possess significant differences underneath the surface. These

\footnotetext{
${ }^{67}$ Pacific Islands Forum Secretariat, 'Forum Trade Ministers Meeting Outcomes Document' (2013), at p. 3.

http://www.forumsec.org/resources/uploads/attachments/documents/2013_FTMM_Outcomes.pdf (May 21, 2014).

${ }^{68}$ See further Forsyth, 'The Developmental Ramifications of Vanuatu's Intellectual Property Commitments on Joining the World Trade Organisation'.

${ }^{69}$ G. Bruce Doern and Markus Sharaput, Canadian Intellectual Property: The Politics of Innovating Institutions and Interests 2000.
} 
superficial similarities are used to legitimize the new regime in terms that are more appropriate to the old regime. In Mexico's case, a copyright regime based in the Continental European tradition and legitimized by moral rights considerations was effectively superseded by an Anglo-American regime, even as it continued to be legitimized largely with reference to moral rights. In Mexican copyright, we can observe the false friends phenomenon, albeit on a smaller scale, in the adoption of the 1997 Ley Federal del Derecho de Autor (LFDA). This law, which implemented the copyright provisions of the 1994 North American Free Trade Agreement (NAFTA) among Mexico, the United States and Canada, ${ }^{70}$ effectively reoriented Mexican copyright policy from its previous Continental European, moral-rights focus, to an Anglo-American, economics-rights focus. However, despite this substantive reform, Mexican copyright law continues to be legitimated as if it were still primarily a moral-rights focused law.

As Viñamata Paschkes notes, and as a cursory reading of the law itself demonstrates, Mexican copyright law recognizes both moral and economic rights. ${ }^{71}$ That said, its moral rights are much stronger and more numerous than those found in US law, which served as the starting point for Mexico's NAFTA-derived reforms. ${ }^{72}$ More importantly from the perspective of this article, laws in the two traditions differ in the legitimation strategies used to justify copyright and emphasize one aspect over the other. ${ }^{73}$

Mexico's initial copyright regime was firmly established in the Continental tradition. Its first copyright-style law was Spain's Real Orden of 1764, which applied to Mexico in its capacity as a Spanish colony and which was primarily a censorship law: it provided authors with the right to defend their work before it would be banned by the Inquisition Tribunal. ${ }^{74}$ Like other Latin American copyright laws, its later laws were modelled on Spain's 1879 Ley de Propieadad Intelectual (Spain's own copyright regime was initially based on the French). ${ }^{75}$ first copyright-style provisions were incorporated into the Código Civil of 1870, although modern Mexican copyright can be dated to Article 28 of the 1917 constitution. The resulting law in the Código Civil (1928) established copyright as a privilege granted by the state rather than an immaterial property right, ${ }^{76}$ as in Anglo-American jurisdictions such as the United States.

\footnotetext{
70 Victor Carlos García Moreno, 'El Capítulo XVII del TLCAN y su Influencia en la Nueva Ley Mexicana del Derecho de Autor'. in Manuel Becerra Ramírez (ed.), Estudios de Derecho Intelectual en Homenaje al Profesor David Rangel Medina, p. 103, at p. 103.

${ }^{71}$ Carlos Viñamata Paschkes, La Propiedad Intelectual. $3^{\text {rd }}$ ed. 2005.

72 For a list and discussion of these moral rights see Viñamata Paschkes, La Propiedad Intelectual, at pp. 39-55.

${ }^{73}$ That said, in practice all copyright regimes identified with both traditions incorporate both moral and economic rights.

${ }^{74}$ Fernando Serrano Migallón, Marco Jurídico del Derecho de Autor en México, $2^{\text {nd }}$ ed. 2008, at pp. 2831.

75 Viñamata Paschkes, La Propiedad Intelectual, at p. 25.

${ }^{76}$ Viñamata Paschkes, La Propiedad Intelectual, at p. 135.
} 
More specifically, its larger objective was to promote public order and the social interest. Copyright, in the Mexican tradition, is a tool to promote the educational and cultural development of Mexican society, including the promotion of national identity. ${ }^{77}$ The Ley Federal del Derecho de Autor of 1947, the first self-contained copyright law and the first to use the term 'derechos de autor', 78 established, among other things, a copyright directorate as part of the Education Ministry (Secretaría de Educación Pública, SEP). The SEP was not primarily focused on the market place. Rather, it had as its mandate (among other things):

- the organization, control and maintenance of a literary and artistic property registry;

- the stimulation of development of theatre in the country and organize contests for authors, actors, and set designers, and to promote their general improvement;

- the organization of artistic exhibitions and other events of cultural interest;

- the guidance of the artistic, cultural, recreational and sporting activities of the federal public sector; and

- the promotion of film, radio, television and print production. ${ }^{79}$

The copyright office, meanwhile, was responsible for the application of the LFDA and 'had as objective the protection of author's rights [copyrights] and to contribute to the safeguarding of the nation's cultural heritage' (emphasis added). ${ }^{80}$ This emphasis on culture, as well as on moral rights, rather than economics can be seen in Mexican legislation and Mexican writings on copyright both before and after the 1997 reforms. The Revista Mexicana del Derecho de Autor, INDAUTOR's predecessor's in-house academic journal features several articles along these lines. In its inaugural edition (January-March 1990), the director general of copyrights, Jose Maria Morfin Patraca writes of copyright as 'the only branch of the law that protects the immortality of the human being: that is, its creativity' (author's translation), ${ }^{81}$ and that the Mexican juridical tradition in this area establishes clearly that Mexico belongs to the school of thought that sees copyright as deriving from human rights.' Elsewhere, scholars write of Mexican copyright's law's objective as being the

\footnotetext{
77 J. Ramón Obón León, 'El Orden Público y el Interés social en la nueva ley federal del derecho de autor', in Manuel Becerra Ramírez (ed.), Estudios de Derecho Intelectual en Homenaje al Profesor David Rangel Medina, 1998, at p. 121.

${ }^{78}$ Serrano Migallón, Marco Jurídico del Derecho de Autor en México, at p. 43.

${ }^{79}$ Viñamata Paschkes, La Propiedad Intelectual, at p. 77.

80 Viñamata Paschkes, La Propiedad Intelectual, at p. 77.

81 Jose Maria Morfin Patraca, Presentación por Jose Maria Morfin Patraca, DG del Derecho de Autor, 1 Revista Mexicana del Derecho de Autor (1990), p. 7, at p. 7.
} 
protection of authors' rights and the safeguarding of the country's cultural heritage, ${ }^{82}$ with the UN Declaration on Human Rights being a key legitimating document. ${ }^{83}$

The 1997 copyright reforms that transformed the Mexican copyright regime from one that emphasized primarily moral rights to an economics-rights-focused regime were driven by a combination of domestic and foreign influences. Domestically, policymakers and stakeholders in the late 1980s and early 1990s viewed the existing regime as exhausted and in need of 'modernization.' This opinion was linked to the general discrediting of the country's statist economic regime in the wake of the debt crisis of the 1980s that plunged Latin America into a 'lost decade' of zero and negative economic growth. Mexican policymakers seized on market-based reforms as the path to salvation, and NAFTA, including its Chapter 17 dealing with intellectual property, was their chosen tool to lock in these reforms. ${ }^{84}$

While Mexican policymakers were seeking a new economic model for their regime, both NAFTA's overall policy direction and the specific content of its intellectual property chapter (Chapter 17) were driven by the United States. The result was a 'new regime [that] differs markedly from its predecessor. The strong moral-rights orientation of Mexican copyright law has been muted and a number of Mexican measures, such as the compulsory licensing of translations of works not available in Spanish after seven years, appear to be in conflict with NAFTA ...' .85 More generally, Jones claims that 'NAFTA continues the evolution of copyright as a publisher's right and largely overlooks the author. ${ }^{86}$ The focus of discussion (in NAFTA) is the material object and not the creative subject, a dubious focal point, one that gives marketing preeminence and that disenfranchises creation.' Obón León, meanwhile, argues that while previous Mexican law was more in the humanist vein, the 1997 reforms bear the imprint of neoliberalism, the result of developed countries implementing a plan of economic globalization. Where before the law had focused on authors/creators, 'the main concern [of NAFTA Chapter 17] was to protect the recording industry, satellite transmissions and the computer industry' (translation by author). ${ }^{87}$ Obón León further notes (correctly) that the 1997 law's extension to cover and reinforce the

82 J. Ramón Obón León, 'La Actualidad del Derecho de Autor en México,' Presentation to WIPO Conference on 'El Derecho de Autor: Un Valor Estratégico para el Futuro', Museo Nacional de Antropología e Historia, 28 June 2003, at p. 9. On file with the author.

83 For example, see Obón León, 'El Orden Público y el Interés social en la nueva ley federal del derecho de autor', at p. 118.

${ }^{84}$ Stephanie R. Golob, 'Beyond the Policy Frontier: Canada, Mexico and the Ideological Origins of NAFTA', in: 55 World Politics (2003), p. 361.

${ }^{85}$ Keith Acheson and Christopher J. Maule, 'Copyright, Contract, the Cultural Industries, and NAFTA,' in Emile G. McAnany, and Kenton T. Wilkinson (eds.), Mass Media and Free Trade: NAFTA and the Cultural Industries, 1996, p. 351, at p. 370.

${ }^{86}$ Steve Jones, 'Mass Communication, Intellectual Property Rights, International Trade, and the Popular Music Industry', in Mass Media and Free Trade, p. 331, at p. 341.

${ }^{87}$ J. Ramón Obón León, Nuevo derecho de los Artistas Intérpretes. 4th ed. 2006, at p. 260. 
rights held by foreign corporations, performers, phonogram producers, audiovisual producers and editors, both foreign and domestic obviates the law's traditional emphasis on protecting the rights of (Mexican) creators and promoting and protecting the development of Mexican national culture. 88

García Moreno similarly remarks that the 1997 law is more concerned with the rights of intermediaries than actual creators, protecting the businesses that profit from authors rather than authors themselves. He further argues that the 1997 Act 'is a law that, rather than addressing the authentic needs of Mexican society, is a product of the compromises made by Mexico at the international level, especially with respect to the NAFTA ... Our country had to cede to American pressure to provide 'adequate' copyright and neighbouring rights protection, for owners and nationals and residents of that country, for purely commercial purposes' ${ }^{89}$ Where before, he continues, Mexican copyright law had been seen as a tool to promote culture and education, the 1997 law transforms it into a commercial law that no longer focuses on these humanist objectives.

NAFTA's de-emphasizing of moral rights in favour of economic rights is also reflected in the requirement (rare in international agreements) that the member countries undertake specific enforcement measures related to copyright, and its requirement that the three NAFTA countries adhere to the Berne Convention except for Article 6bis, which deals with moral rights. In contrast, Article 6bis is mentioned in the otherwise similar TRIPS Agreement. ${ }^{90}$ This exclusion 'represents the clearest indication that [NAFTA] represent[s] a further industrialization of culture and are industry-driven. They also represent further support for the definition of 'ownership' as being vested in producers and manufacturers, an outcome of such industrialization'. ${ }^{91}$

On the former, NAFTA takes the unusual step of requiring that the three countries criminalize and penalize commercial copyright violations (Article 1717.1). Mexico was the specific target of these provisions, as the United States believed it 'did not have a comprehensive enforcement mechanism for intellectual property'.92

Despite the transformation of Mexican copyright law from a Mexican author-centric tool of cultural and national development to an international, owner-focused economic policy,

\footnotetext{
88 Obón León, 'La Actualidad del Derecho de Autor en México', at p. 11.

${ }^{89}$ Victor Carlos García Moreno, 'El Capítulo XVII del TLCAN y su Influencia en la Nueva Ley Mexicana del Derecho de Autor', in Estudios de Derecho Intelectual en Homenaje al Profesor David Rangel Medina, at pp. 115-116.

${ }^{90}$ García Moreno, 'El Capítulo XVII del TLCAN y su Influencia en la Nueva Ley Mexicana del Derecho de Autor', at p. 105.

${ }^{91}$ Jones, 'Mass Communication, Intellectual Property Rights, International Trade, and the Popular Music Industry', at p. 343.

${ }^{92}$ Barry Appleton, Navigating NAFTA: A Concise User's Guide to the North American Free Trade Agreement 1994, at p. 128.
} 
Mexican copyright continues to be justified in terms of the old regime. When the LFDA was published in 1996 as part of the legislative process, the government framed the reforms as a defence of the national culture. ${ }^{93}$ This focus on the production and preservation of Mexican culture is re- stated in article 1 of the 1997 LFDA, according to which, copyright's objective is 'to safeguard and promote the Nation's cultural heritage; to protect the rights of authors, performers, as well as publishers, producers and broadcasters, in connection to their literary or artistic works in all their forms, their publications, their phonograms or video recordings, and their broadcasts, as well as other intellectual-property rights' (translation by author).

Copyright's role in safeguarding the nation's cultural heritage continues to be raised as an issue in the post-NAFTA era. ${ }^{94}$ Viñamata Paschkes argues that the LFDA's main subject is the protection of 'intellectual and artistic activity, rather than a commercial interest'. 95 Writing in the introduction to the primary text on Mexican copyright law, ${ }^{96}$ Kamil Idirs, former secretary general of the World Intellectual Property Organization (WIPO) remarks that copyright is seen in Mexico as the way in which Mexican and universal culture is safeguarded and protected. ${ }^{97}$ According to Serrano Migallón, discussing the post-1997 copyright regime:

In the past, as today, derecho de autor norms are not just economic or market norms; its ultimate purpose has been always of a much more transcendent nature, its juridical norms destined to preserve the dignity of the labours of creators of these works of ingenuity and the spirit, in a way that allows, regarding respect and remuneration, an apt environment for creation and its enjoyment (author's translation). ${ }^{98}$

Among those lawyers working on copyright there is a recognition of this cognitive dissonance, that an economic law continues to be justified in terms of moral rights. As copyright lawyer Manuel Morante remarked in an interview with the co-author'99, 'Today the derecho patrimonial (economic right) takes precedence over moral rights.' However, as copyright lawyer and scholar (from the National Autonomous University of Mexico, UNAM)

\footnotetext{
93 Obón Léon, ‘El Orden Público y el Interés social en la nueva ley federal del derecho de autor’, at p. 123.

${ }^{94}$ E.g., Gabriela Barrios Garrido, 'Internet y lo que falta en la nueva Ley Federal del Derecho de Autor', in Estudios de Derecho Intelectual en Homenaje al Profesor David Rangel Medina, at p. 354, http://www.bibliojuridica.org/libros/1/164/21.pdf (May 21, 2014), discussing discussing copyright's role in the digital era.

95 Viñamata Paschkes, La Propiedad Intelectual, at pp. 79-80.

${ }^{96}$ Serrano Migallón, Marco Jurídico del Derecho de Autor en México.

${ }^{97}$ Kamil Idirs, 'Preface', in Fernando Serrano Migallón, Marco Jurídico del Derecho de Autor en México.

${ }^{98}$ Serrano Migallón, Marco Jurídico del Derecho de Autor en México, at p. 4.

${ }_{99}$ Manuel Morante Soria. Copyright Lawyer, Arochi, Marroquín \& Linder, S.C. Interview by co-author. Mexico City. December 3, 2009.
} 
Cesar Callejas also noted in an interview with the author, 'In Mexico there is still the myth that industrial property protects commerce and derecho de autor protects artistic ideas (moral rights).'100

In Mexico, therefore, we have a situation where significant copyright reforms were undertaken, transforming the moral-rights-focused regime into a markedly different economic-rights-focused one. However, it continues to be justified and legitimized in terms of a moral-rights regime that, while not completely eliminated, has been roundly subordinated to what is now primarily a commercial law. This justification, in terms of a regime that no longer exists, complicates the ability to have a clear discussion of the merits and drawbacks of the new regime. Especially when the public is increasingly being directly affected by copyright law, thanks to the spread of digital technology and file sharing, ${ }^{101}$ an understanding of the actual purposes and effects of copyright and IP is crucial to a wellinformed policy discussion.

\section{The Perils of False Friends}

In this conclusion we reflect on the false friends concept at three different levels of generality.

At its most general level, the concept of false friends demonstrates the value that sociolinguistics can bring to the difficult and contested terrain of translating legal concepts. Although attention has been paid to the value of sociolinguistics in a legal context, it has mostly been at the level of courtroom interactions. ${ }^{102}$ However, given the recent emphasis on translation as part of the growing awareness of the dynamics of pluralism in transnational legal ordering, sociolinguistic insights may also prove important in a transnational context. For example, sociolinguistics offers important insights into the way discursive practices constrain the ways in which concepts are able to be framed, and also how they perpetuate certain types of domination.

At a second level, we suggest that the concept of false friends may be a useful device for facilitating intercultural legal pluralism generally. It draws attention to situations where there is a superficial similarity between concepts, meaning that the problems of miscommunication are not readily apparent. It is highly likely that this is a far more frequent problem than the paucity of the literature suggests, especially perhaps in countries where a pidgin or creole is spoken and the necessity for translators is therefore often not considered necessary. For example, in discussing the Bislama (pidgin English spoken in Vanuatu) concept of human rights, Taylor states:

${ }^{100}$ Cesar Benedicto Callejas. Director, Patents and Trademarks; National Autonomous University of Mexico (UNAM). Interview by co-author. Mexico City. October 26, 2009.

${ }^{101}$ See Blayne Haggart, Copyfight: The global politics of digital copyright reform 2014.

102 Justin Richland, Arguing with Tradition: The Language of Law in Hopi Tribunal Court 2008, at pp. 61-62. 
In particular, ... the concept of raet in Bislama does not easily equate to the apparently naturalised terms of Western notions of liberal democracy and individual equality that are implied in the 'rights' of 'human rights'. Rather, related as it is to privileges of status that are acquired through ritual and other social mechanisms, it is primarily understood to be relational and hierarchical. To have raet is to hold the power to 'overem' ('to go over') others; the power to assert one's dominance and impose one's will over others ... Within this schema therefore, ipso fucto, one group or person's 'freedoms' imply another person's 'penalties.'103

However, while the consequences and likelihood of a false friends problem increase with the distance between regimes, they are likely to be present even in similar regimes. Looking at our two cases, Vanuatu's regime is obviously more different from the global IP regime than Mexico's is from the United States. Adopting wholesale a WTO-style IP regime will fundamentally change how Vanuatu can manage knowledge. In contrast, NAFTA shifted the orientation and emphasis of Mexican copyright policy, but did not completely transform it because the Mexican copyright regime already addressed both economic and moral rights in the European tradition(s). Nevertheless, that the Mexican regime continued to be justified in terms of the language of the previously existing regime is evidence of a false friends effect: a 'new' policy welcomed based on the language of the old.

Finally, at its most specific level, this paper has highlighted two particular instances of false friends in the context of intellectual property. Just as good second language teachers have a certain set of false friends that they warn language learners about, so we have started the process here of identifying specific false friends that can occur at a conceptual legal level arising from superficial similarities over the regulation of knowledge and other intangible valuables. This identification of the false friends problem is of assistance in a number of ways. First, it suggests that there is a need for a mechanism to correct the false 'translation,' to avoid IP maximalist policies being unquestioningly introduced in some developing countries, and to help citizens understand the real potential pitfalls and opportunities of the new legal regimes. This translation can be performed by a range of intermediaries, such as national IP office staff, or northern activists working to convince developing countries not to sign 'bad' IP agreements. Often such activists will assume that the population will be opposed to such laws, and may not be aware of the education and explanation that needs to be done up front to ensure that there is mutual understanding about the issues at stake.

The existence of the false friends problem also raises real questions about actors' full agency and self-determination over domestic intellectual property policy in developing countries. False friends create blind spots in which one is unaware that there is even a problem - the issue of 'known unknowns,' to quote an infamous former American Secretary

103 Jack Taylor, 'The Social life of Rights: Gender Antagonism, Modernity and rate in Vanuatu', in: 19 The Australian Journal of Anthropology (2008 ), p. 165, at p. 176. 
of Defence. They are likely to exacerbate the power disparities between the global IP powers and Least Developed Countries like Vanuatu and developing countries like Mexico, since it is hard to know that you (policymakers or the general public) are striking a 'bad' deal - or, more precisely, a deal that does not do what you think it will do - if you do not fully understand the terms being discussed. While this is obviously a problem for developing countries, it should also be of concern to international organizations like the World Intellectual Property Organisation and the WTO, as well as the global IP powers. The long-term sustainability of the global (Western) IP regime requires that it be seen as legitimate and fair to all those involved. False friends, and the advantages they provide to more powerful countries and organizations, strike at the heart of the legitimacy of these agreements.

Looking to the approach taken by Diana Eades regarding Aboriginal English in Australian courts, we argue that similar directions and translation mechanisms are required in the context of information sessions about, negotiations over, and implementation of, global regulatory orders such as global intellectual property regimes. In the absence of awareness of such fundamentally different discursive frameworks, it is virtually impossible to have the sort of robust debates that are necessary for developing countries to engage with the advantages and disadvantages of the global legal norms on offer. Addressing the issue of false friends is not a panacea for the structural imbalances between countries negotiating on intellectual property, or other issues. The problem of coercion, through political or economic pressure, such as via FTAs will likely continue. However, it is preferable, as a fundamental principle of justice, that there is at least awareness at a political and grassroots level of the extent of the trade-off that has been made. 